\title{
VECTOR AUTOREGRESSIVE STABILITY CONDITION CHECK UNTUK PEMODELAN DAN PREDIKSI SUMBER PENERIMAAN PABEAN BELAWAN
}

\author{
Mia Anastasia Sinulingga ${ }^{1}$, Di Asih I Maruddani ${ }^{2}$, Abdul Hoyyi ${ }^{3}$ \\ 1,2,3 Departemen Statistika, Fakultas Sains dan Matematika, Universitas Diponegoro \\ e-mail :maruddani@gmail.com
}

\begin{abstract}
Customs Intermediate are an institution that is responsible for regulating the flow of export and import trade activities in the Customs Area with the revenue coming fromimport duties and export duties. The time series data from the cus toms acceptance component import dan export which have a relationship between variables. Vector Autoregressive is a statistical method used in predicting and evaluating interrelationships between variables. The purpose of this study is to obtain a model for predicting import and export by using the VAR model and detecting the stability of the model. Model requirements are said to be stable if all modulus values from roots characteristic of coefficient matrices $\leq 1$ that the predicted results can be verified. The data is divided into in sample data starting from January 2010 to June 2018 and out sample data starts from July 2018 until December 2018. The results of data analysis in this study, the model obtained for prediction is the VAR model (4) and there is a direct relationship between both variables. The VAR (4) residual model fulfills the assumption of white noise, while the as sumption of multivariate normality is not fulfilled. Based on out sample the value of MAPE for import variables $18.42 \%$, export $12.94 \%$ shows the VAR model (4) has good predictive capabilities that can be used for predicting future periods. Predicted results on import show fluctuations duing the period of January to December 2019 while in the export shows increase during the period of January to December 2019.
\end{abstract}

Keywords: Import, Export, VAR, Granger caus ality, VAR stability, MAPE.

\section{PENDAHULUAN}

Setiap negara yang berdaulat berupaya untuk mensejahterakan rakyatnya. Upaya peningkatan kesejahteraan umum dilakukan melalui upaya peningkatan pertumbuhan ekonomi melalui proses pembangunan nasional negara tersebut. Indonesia dalam mewujudkan kesejahteraan sosial memiliki kendala baik dalam negeri maupun luar negeri.

Melambatnya perekonomian dunia merupakan kendala yang berasal dari luar negeri. Hal tersebut mengakibatkan perekonomian dalam negeri turut terguncang karena nilai tukar rupiah terhadap dolar semakin melemah, sehingga menyebabkan kegiatan perdagangan ekspor impor menjadi turun. Hal itu akan berdampak pada lambatnya pemenuhan targettarget pembangunan nasional. Tantangan bagi Bea Cukai Tipe Madya Pabean dalam mengawasi dan mengecek barang masuk dan barang keluar melalui jalur pelabuhan Belawan dengan faktor penerimaan pabean berasal dari bea masuk serta bea keluar.

Pada penelitian Wahyuli (2007), terdapat hubungan keterkaitan dan pengaruh timbal balik antara produksi, konsumsi, ekspor, impor dan harga minyak bumi sehingga layak melakukan analisis dengan model Vector Autoregressive. VAR digunakan untuk pemodelan beberapa variabel endogen yang memiliki hubungan antar variabel endongennya yang dipengaruhi oleh waktu sebelumnya. VAR diperkenalkan oleh Sims (1972) sebagai pengembangan dari pemikiran Granger dan Clive (1969). Granger menyatakan bahwa apabila dua variabel memiliki hubungan kausalitas, maka informasi masa lalu dapat digunakan untuk meramalkan antar variabel yang terlibat. Variabel-variabel yang terlibat pada pemodelan VAR tidak perlu dibedakan menjadi variabel endogen maupun eksogen, semua variabel yang terlibat memiliki kedudukan yang sama sebagai variabel endogen. 


\section{TINJAUAN PUSTAKA}

\subsection{Bea Cukai}

Bea cukai kawasan pabean adalah kawasan dengan batas-batas tertentu di pelabuhan laut, bandar udara atau tempat lain yang ditetapkan untuk lalu-lintas barang yang sepenuhnya berada di bawah pengawasan Direktorat Jendral Bea dan Cukai.

\subsection{Bea Masuk}

Bea Masuk adalah pungutan negara terhadap barang yang diimpor sesuai dengan ketentuan Undang-Undang yang berlaku, barang impor tersebut kemudian dikenakan tarif berdasarkan klasifikasi barang. Penetapan tarif Bea Masuk atas barang yang diimpor dikelompokkan berdasarkan sistem klasifikasi barang (Pasal 12) dalam Undang-undang No 17 Tahun 2006 tentang Perubahan Undang-undang No 10 Tahun 1995 tentang Kepabeanan.

\subsection{Bea Keluar}

Bea keluar merupakan pajak yang dikenakan pada barang yang diekspor (KBBI). Produk-produk yang dikenakan tarif pada ekspor telah ditentukan sesuai aturan yang telah dibuat dalam keputusan Kementerian Keuangan Republik Indonesia No.461/KMK/04/2018 Tentang Penetapan Harga Ekspor Untuk perhitungan Bea keluar. Hanya beberapa produk ekspor yang dikenai biaya bea keluar seperti: hasil produk pertanian, hasil hutan, hasil perikanan, hasil pertambangan, hasil industri dan jasa.

\subsection{Runtun Waktu}

Menurut Widarjono (2005), data runtun waktu merupakan sekumpulan observasi dalam rentang waktu tertentu.Suatu pengamatan memiliki model runtun waktu jika memenuhi hal berikut:

1. Interval antar waktu $t$ dapat dinyatakan dalam satuan waktu yang sama (identik).

2. Adanya ketergantungan antara pengamatan $Y_{t}$ dengan $Y_{t+k}$ yang dipisahkan oleh jarak waktu berupa kelipatan $\Delta_{t}$ sebanyak $k$ kali (dinyatakan sebagai lag $k$ ).

\subsection{Model Vector Autoregressive (VAR)}

Model Vector Autoregressive orde $\mathrm{p}$ atau VAR $(p)$ yang dibangkitkan dari model $\operatorname{AR}(p)$ dengan bentuk umum dari model Autoregressive orde $\mathrm{p}(\operatorname{AR}(p))$ yaitu:

$Y_{t}=\phi_{1} Y_{t-1}+\phi_{2} Y_{t-2}+\phi_{3} Y_{t-3}+\cdots+\phi_{p} Y_{t-p}+e_{t}$

Vector Autoregressive (VAR) merupakan metode runtun waktu multivariat yang dapat menjelaskan variabel endogen dari data masa lalu variabel tersebut dan variabel endogen lainnya. Vector Autoregressive (VAR) adalah metode ekonometrik yang berguna untuk menguji antar variabel pada model yang memiliki dampak dinamis (Ozcelebi, 2011). berikut:

Model persamaan Vector Autoregressive orde $p$ (VAR $(p)$ ) secara umum sebagai

$$
Y_{j t}=\alpha_{j}+\sum_{i=1}^{p} \beta_{j i} Y_{1, t-i}+\sum_{i=1}^{p} \theta_{j i} Y_{2, t-i}+\cdots+\sum_{i=1}^{p} \gamma_{K i} Y_{K, t-i}+\varepsilon_{j t}
$$

\subsection{Stasioneritas Data}

\subsubsection{Stasione ritas dalam Varian}

Pengujian stasioneritas dalam varian dapat digunakan dengan transformasi Box-Cox. Transformasi Box-Cox merupakan pangkat yang dirumuskan sebagai berikut (Wei, 2006):

$$
T\left(Y_{t}\right)=\frac{Y_{t}^{(\lambda)}-1}{\lambda}
$$


Dengan $Y_{t}$ merupakan variabel pengamatan pada waktu ke-t.

\subsubsection{Stasione ritas dalam Rataan}

Stasioneritas dalam rataan berarti fluktuasi data berada di sekitar nilai rata-rata yang konstan, tidak dipengaruhi oleh berubahnya waktu pengamatan. Dengan pengujian sebagai berikut:

Hipotesis

$\mathrm{H}_{0}: \gamma=0$ (yang berarti $Y_{t}$ mengandung akar unit atau tidak stasioner)

$\mathrm{H}_{1}: \gamma<0$ (yang berarti $Y_{t}$ tidak mengandung akar unit atau stasioner)

Statistik uji

$$
\tau=\frac{\widehat{\gamma}}{S E(\widehat{\gamma})}
$$

Kriteria uji

$\mathrm{H}_{0}$ ditolak jika nilai $\tau<$ nilai statistik $\mathrm{DF}(\alpha, \mathrm{n})$ atau $p$-value $<\alpha$.

\subsection{Penentuan Lag Optimal}

Menurut Ariefianto (2012) penentuan $p$ dilakukan berdasarkan formula $P \max =T^{\frac{1}{3}}$ dengan $\mathrm{T}$ menyatakan banyaknya pengamatan dalam membentuk model. Penentuan jumlah lag yang akan digunakan ke dalam model VAR dapat ditentukan beberapa kriteria dalam Lütkepohl (2005). Salah satunya kriteria AIC dengan rumus sebagai berikut:

$$
\operatorname{AIC}(p)=\ln \left|\widehat{\boldsymbol{\Sigma}}_{u}(p)\right|+\frac{2 p \mathrm{~K}^{2}}{n}
$$

\subsection{Estimasi Parame ter Model VAR}

Estimasi parameter model VAR pada paper ini menggunakan metode Ordinary Least Square (OLS). Estimasi OLS diperoleh dengan meminimalkan jumlah kuadrat residual. Parameter yang diestimasi dalam model VAR (2) menggunakan OLS adalah $\beta_{j i}$ dan $\theta_{j i}$ dengan $j=1,2$ dan $i=1,2$. Perhitungan OLS dengan 2 variabel dengan model VAR sebagai berikut:

$$
\begin{aligned}
& Y_{1, t}=\alpha_{1}+\beta_{11} Y_{1, t-1}+\beta_{12} Y_{1, t-2}+\theta_{11} Y_{2, t-1}+\theta_{12} Y_{2, t-2}+\varepsilon_{1, t} \\
& Y_{2, t}=\alpha_{2}+\beta_{21} Y_{1, t-1}+\beta_{22} Y_{1, t-2}+\theta_{21} Y_{2, t-1}+\theta_{22} Y_{2, t-2}+\varepsilon_{2, t}
\end{aligned}
$$

Model VAR (2) pada persamaan (6) dan (7) dapat dinyatakan dalam bentuk matriks sebagai berikut:

$$
\left[\begin{array}{l}
Y_{1, t} \\
Y_{2, t}
\end{array}\right]=\left[\begin{array}{l}
\alpha_{1} \\
\alpha_{2}
\end{array}\right]\left[\begin{array}{ll}
\beta_{11} & \theta_{11} \\
\beta_{21} & \theta_{21}
\end{array}\right]\left[\begin{array}{l}
Y_{1, t-1} \\
Y_{2, t-1}
\end{array}\right]+\left[\begin{array}{ll}
\beta_{12} & \theta_{12} \\
\beta_{22} & \theta_{22}
\end{array}\right]\left[\begin{array}{l}
Y_{1, t-2} \\
Y_{2, t-2}
\end{array}\right]+\left[\begin{array}{l}
\varepsilon_{1, t} \\
\varepsilon_{2, t}
\end{array}\right]
$$

Persamaan (8) dapat dinyatakan dalam bentuk model linier sebagai berikut:

Cara mengkuadratkan error sebagai berikut:

$$
\boldsymbol{Y}=\boldsymbol{A} \boldsymbol{\delta}+\boldsymbol{\varepsilon}
$$

$$
\begin{aligned}
& \varepsilon=\boldsymbol{Y}-\boldsymbol{A} \boldsymbol{\delta} \\
& \mathcal{\varepsilon}^{\prime} \varepsilon=(\boldsymbol{Y}-\boldsymbol{A} \boldsymbol{\delta})^{\prime}(\boldsymbol{Y}-\boldsymbol{A} \boldsymbol{\delta}) \\
& \mathcal{\varepsilon}^{\prime} \varepsilon=\boldsymbol{Y}^{\prime} \boldsymbol{Y}-\boldsymbol{Y}^{\prime} \boldsymbol{A} \boldsymbol{\delta}-\boldsymbol{\delta}^{\prime} \boldsymbol{A}^{\prime} \boldsymbol{Y}+\boldsymbol{\delta}^{\prime} \boldsymbol{A}^{\prime} \boldsymbol{A} \boldsymbol{\delta} \\
& \mathcal{\varepsilon}^{\prime} \varepsilon=\boldsymbol{Y}^{\prime} \boldsymbol{Y}-2 \boldsymbol{A}^{\prime} \boldsymbol{Y}+\mathbf{2} \boldsymbol{A}^{\prime} \boldsymbol{A} \boldsymbol{\delta}
\end{aligned}
$$

Dimana $\boldsymbol{\varepsilon}^{\prime} \boldsymbol{\varepsilon}$ adalah jumlah kuadrat error (SSE) yang ingin diminimalkan. Syarat untuk meminimalkan error adalah turunan pertama dari $\boldsymbol{\varepsilon}^{\prime} \boldsymbol{\varepsilon}$ terhadap $\boldsymbol{\delta}$ adalah $\mathbf{0}$. Kemudian syarat cukup untuk didapatkan error minimal adalah turunan kedua dari $\boldsymbol{\varepsilon}^{\prime} \boldsymbol{\varepsilon}$ terhadap $\boldsymbol{\delta}$ adalah lebih besar dari 0. Dapat dilihat untuk turunan pertama diperoleh hasil seperti berikut:

$$
\frac{\partial \varepsilon^{\prime} \varepsilon}{\partial \delta}=2 A^{\prime} Y+2 A^{\prime} A \delta=0
$$


Untuk turunan kedua diperoleh hasil:

$$
\frac{\partial^{2} \varepsilon^{\prime} \varepsilon}{\partial \boldsymbol{\delta} \partial \boldsymbol{\delta}}=\mathbf{2} \boldsymbol{A}^{\prime} \boldsymbol{A}
$$

$\boldsymbol{A}^{\prime} \boldsymbol{A}$ merupakan matriks definit positif, yaitu matriks simetri yang semua unsur diagonalnya bernilai positif. Karena $\boldsymbol{A}^{\prime} \boldsymbol{A}$ merupakan definit positif maka

$$
\frac{\partial^{2} \varepsilon^{\prime} \varepsilon}{\partial \delta \partial \delta}=2 A^{\prime} A>0
$$

Selanjutnya,

$$
\boldsymbol{A}^{\prime} \boldsymbol{Y}=\boldsymbol{A}^{\prime} \boldsymbol{A} \boldsymbol{\delta}
$$

Dari persamaan (14) diperoleh rumus kuadrat terkecil:

$$
\delta=\left(A^{\prime} A\right)^{-1} A^{\prime} Y
$$

\subsection{Uji Kausalitas Granger}

Uji kausalitas dilakukan untuk melihat apakah terdapat hubungan sebab akibat antara variabel yang terlibat dalam model VAR. Jika terjadi kausalitas dalam perilaku ekonomi maka di dalam model ekonometrika ini tidak terdapat variabel eksogen, semua variabel merupakan variabel endogen.

Hipotesis

$\mathrm{H}_{0}: \gamma=0$ (yang berarti $Y_{t}$ mengandung akar unit atau tidak stasioner)

$\mathrm{H}_{1}: \gamma<0$ (yang berarti $Y_{t}$ tidak mengandung akar unit atau stasioner)

Statistik uji

dengan:

$$
F=\frac{\left(R S S_{R}-R S S_{U R}\right) / m}{R S S_{U R} /(n-K)}
$$

$R_{R} \quad$ : Residual Sum of Square dari regresi bersyarat (restricted)

$R S S_{U R} \quad:$ Residual Sum of Square dari regresi bersyarat (unrestricted)

$\mathrm{m} \quad$ : banyaknya lag

$\mathrm{n} \quad$ : banyaknya data pengamatan

$\mathrm{K} \quad$ : banyaknya parameter yang diestimasi pada model

Kriteria Penolakan

$\mathrm{H}_{0}$ ditolak jika $F>F_{(\alpha, m,(n-k))}$ atau nilai prob $<\alpha$

\subsection{Deteksi Stabilitas VAR}

Suatu model dikatakan stabil jika memenuhi persamaan:

$\operatorname{det}\left(\boldsymbol{I}_{k}-\boldsymbol{\beta}_{1} m\right) \neq 0$ untuk modulus $(\mathrm{m}),|m| \leq 1$.

dengan kondisi dari nilai eigen dari matriks $\boldsymbol{\beta}_{1}$ memiliki modulus kurang dari 1. Jika $Y_{t}$ adalah sebuah VAR $(p)$ pada persamaan (16), sesuai dengan model error VAR (1)

$$
\boldsymbol{Y}_{t}=\boldsymbol{a}+\boldsymbol{\beta} Y_{t-1}+\varepsilon_{t}
$$

Sehingga dapat didefinisikan dengan

$$
\begin{array}{rlc}
\boldsymbol{Y}_{t}=\left[\begin{array}{c}
y_{t} \\
y_{t-1} \\
\vdots \\
y_{t} P+1
\end{array}\right], & & \boldsymbol{a}=\left[\begin{array}{c}
a \\
0 \\
\vdots \\
0
\end{array}\right], \\
\left(K_{P} \mathrm{X} 1\right) & & \left(K_{P} \mathrm{X} 1\right) \\
\boldsymbol{\beta} & =\left[\begin{array}{ccccc}
\beta_{1} & \beta_{2} & \cdots & \beta_{P-1} & \beta_{P} \\
I_{K} & 0 & \cdots & 0 & 0 \\
0 & I_{K} & & 0 & 0 \\
\vdots & & \ddots & \vdots & \vdots \\
0 & 0 & \cdots & I_{K} & 0
\end{array}\right], & \varepsilon_{t}=\left[\begin{array}{c}
\varepsilon_{t} \\
0 \\
\vdots \\
0
\end{array}\right], \\
& & \left(K_{P} \mathrm{X} K_{P}\right)
\end{array}
$$




\subsection{Pengujian Asumsi Residual}

\subsubsection{Uji Independensi Residual}

Pada kasus multivariat, uji independensi menggunakan uji Portmanteau (Lütkepohl, 2005).

Hipotesis

$\mathrm{H}_{0}: \rho_{1}=\rho_{2}=\rho_{3}=\cdots=\rho_{k}=0$ (tidak ada korelasi residual antar lag)

$\mathrm{H}_{1}$ : terdapat paling sedikit satu $\rho_{i} \neq 0$ dengan $i=1,2, \ldots, k$ (terdapat korelasi residual antar lag)

Taraf signifikansi $\alpha$

Statistik Uji

$$
Q_{p}=n \sum_{j=1}^{p} \operatorname{tr}\left(\widehat{\boldsymbol{C}}_{j} \widehat{\boldsymbol{C}}_{0}^{-1} \widehat{\boldsymbol{C}}_{j} \widehat{\boldsymbol{C}}_{0}^{-1}\right)
$$

Kriteria Penolakan

$\mathrm{H}_{0}$ ditolak jika nilai prob $<\alpha$ atau $Q_{h} \geq \chi_{\left(K^{2} p ; \alpha\right)}^{2}$

\subsubsection{Uji Multinormal Residual}

Pengujian asumsi multinormal residual.

Hipotesis

$\mathrm{H}_{0}$ : residual dari model VAR berdistribusi multinormal

$\mathrm{H}_{1}$ : residual dari model VAR tidak berdistribusi multinormal

Taraf signifikansi $\alpha$

Statistik Uji

$$
\lambda_{s k}=\lambda_{s}+\lambda_{k}
$$

Kriteria Penolakan

Ho ditolak jika $\lambda_{s k} \geq \chi_{(2 K)}^{2}$ atau $p-$ value $<\alpha$

\subsection{Impulse Respon Function (IRF)}

Menurut Juanda dan Junaidi (2012) penelusuran pengaruh guncangan sebesar satu standar deviasi yang dialami oleh satu variabel di dalam sistem terhadap nilai-nilai semua variabel saat ini dan beberapa periode mendatang disebut sebagai teknik Impulse Respon Function (IRF).

\subsection{Forecast Error Decomposition Variance (FEDV)}

Analisis Forecast Error Decomposition Variance (FEDV) bertujuan untuk memprediksi kontribusi presentase varian setiap peubah karena adanya perubahan peubah tertentu dalam sistem. FEDV digunakan untuk menggambarkan relatif pentingnya setiap variabel dalam sistem karena adanya guncangan (shock) (Juanda \& Junaidi, 2012).

\subsection{Ketepatan Me tode Prediksi}

Ketepatan metode prediksi dihitung dengan Mean Absolute Percentage Error (MAPE) dengan rumus sebagai berikut:

$$
M A P E=\frac{100}{n} \sum_{t=1}^{n}\left|\frac{X_{t}-F_{t}}{X_{t}}\right|
$$




\section{METODOLOGI PENELITIAN}

\subsection{Sumber Data}

Data yang digunakan dalam penulisan penelitian ini adalah data sekunder, yaitu data laporan bulanan Kantor Pengawasan dan Pelayanan Bea dan Cukai Pabean Belawan periode Januari 2010 sampai dengan Desember 2018.

\subsection{Variabel Penelitian}

Variabel yang digunakan dalam penulisan tugas akhir adalah data bulanan Bea Masuk (BM) dan Bea Keluar (BK) pada Kantor Pengawasan dan Pelayanan Bea dan Cukai Pabean Belawan sejak Januari 2010 sampai dengan Desember 2018.

\subsection{Langkah-Langkah Penelitian}

1. Menentukan data yang akan digunakan yaitu data runtun waktu bea masuk dan bea keluar.

2. Melakukan uji stasioneritas pada data dalam varian jika tidak stasioner maka dilakukan transformasi Box-Cox.

3. Melakukan uji stasioneritas dalam rataan dengan Uji Dickey-Fuller jika tidak stasioner maka dilakukan diferensi hingga diperoleh stasioner pada tingkat yang sama.

4. Menentukan lag optimal berdasarkan Akaike Information Criteria.

5. Melakukan pemodelan VAR berdasarkan lag terbaik.

6. Melakukan uji kausalitas Granger untuk mengetahui hubungan antar variabel.

7. Melakukan deteksi stabilitas model VAR melalui Root Characteristic Polynomial. Jika nilai modulus < 1 maka model VAR digolongkan model stabil. Jika tidak stabil, maka model VAR tidak layak untuk dilanjutkan ke tahap prediksi.

8. Melakukan uji asumsi residual dalam model VAR yang harus dipenuhi adalah independensi dan normalitas residual.

9. Melakukan penanganan dengan transformasi terhadap data jika terjadi pelanggaran asumsi residual.

10. Melakukan Analisis Impulse Response Function (IRF) dan Analisis Forecast Error Decomposition Variance (FEDV).

11. Menghitung nilai Mean Absolute Prencentage Error (MAPE) untuk mengevaluasi ketepatan peramalan.

\section{HASIL DAN PEMBAHASAN}

\subsection{Uji Stasioneritas}

\subsubsection{Uji Stasione ritas dalam Varian BM dan BK}

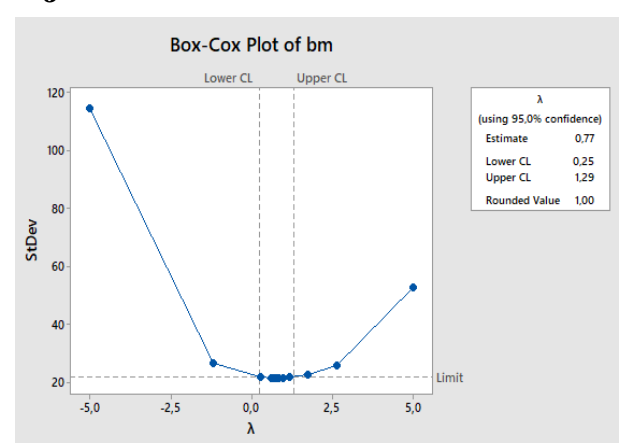

Gambar 1. Plot Box Cox untuk BM

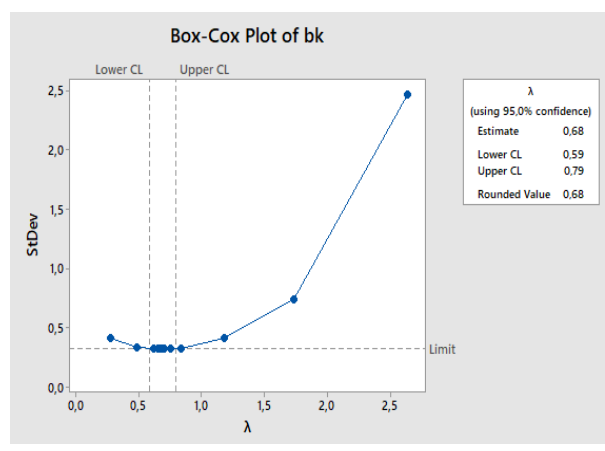

Gambar 2. Plot Box Cox untuk BK 
Dilihat dari Gambar 1 dan Gambar 2 diperoleh bahwa batas atas, batas bawah, rounded value, dan lambda estimate masing-masing variabel tidak sama. Jika akan dilakukan transformasi, maka transformasi yang dipakai akan berbeda-beda sesuai lambda estimate masing-masing. Padahal dalam analisis multivariat perlakuan terhadap semua variabel harus sama, oleh karena itu menurut Shofiyah et al. (2009) dalam Nisa (2010) transformasi tidak perlu dilakukan dan data dapat dianggap stasioner dalam varian.

\subsubsection{Uji Stasioneritas dalam Rataan BM dan BK}

Hipotesis

$\mathrm{H}_{0}: \gamma=0$ terdapat akar unit (data runtun waktu tidak stasioner)

$\mathrm{H}_{1}: \gamma<0$ tidak terdapat akar unit (data runtun waktu stasioner)

Taraf signifikansi $\alpha=5 \%$

Statistik Uji

Berdasarkan Lampiran 2 diperoleh nilai uji stasioneritas BM Dickey-Fuller (DF) $=-3.405644$ dan $p$-value $=0.0129$ dan nilai uji stasioneritas BK Dickey-Fuller $(\mathrm{DF})=-4.210660$ dan $p$-value $=0.0010$.

Kriteria Uji

Menolak $\mathrm{H}_{0}$ jika $p$-value $<\alpha$ atau nilai DF $>$ critical value $\mathrm{DF}(5 \%)$.

Keputusan

Diperolah nilai $p$-value $(\mathrm{BM})=0.0129<\alpha=0.05$ sehingga diambil keputusan untuk menolak $\mathrm{H}_{0}$.

Diperolah nilai $p$-value $(\mathrm{BK})=0,0010<\alpha=0.05$ sehingga diambil keputusan untuk menolak $\mathrm{H}_{0}$.

Kesimpulan

Pada taraf signifikansi 5\% dapat disimpulkan bahwa data BM dan BK tidak mengandung akar unit atau sudah stasioner dalam level (data asli).

\subsection{Penentuan Lag Optimal}

Tabel 3. Nilai Akaike Information Criteria (AIC)

\begin{tabular}{cc}
\hline Kriteria & AIC \\
\hline Lag 1 & 8.518497 \\
Lag 2 & 8.454398 \\
Lag 3 & 8.494739 \\
Lag 4 & $8.347380^{*}$ \\
Lag 5 & 8.412730
\end{tabular}

Pada Tabel 3 dapat diketahui hasil pengujian untuk lima lag yang dicobakan. Nilai AIC terkecil terdapat pada lag ke 4 yaitu 8.347380 sehingga estimasi model VAR akan menggunakan lag 4.

\subsection{Model VAR Lag 4}

Hasil estimasi OLS dari parameter masing-masing variabel, dengan persamaan sebagai berikut:

$$
\begin{aligned}
\mathrm{BM}= & 13.4677610021+0.415525516978 * \mathrm{BM}(-1)+0.155592518908 * \mathrm{BM}(-2)- \\
& 0.0915261272713 * \mathrm{BM}(-3)+0.327956634411 * \mathrm{BM}(-4)-12.5431999451 * \mathrm{BK}(-1)+ \\
& 25.610984559 * \mathrm{BK}(-2)-1.58832310159 * \mathrm{BK}(-3) 10.2171979963 * \mathrm{BK}(-4) \\
\mathrm{BK}= & 0.246086473297-0.000838052009734 * \mathrm{BM}(-1)-0.00375081289901 * \mathrm{BM}(-2)+
\end{aligned}
$$


ISSN: 2339-2541

JURNAL GAUSSIAN, Volume 9, Nomor 2, Tahun 2020, Halaman 204-214

Online di: https://ejournal3.undip.ac.id/index.php/gaussian/

$0.000912046162506 * \mathrm{BM}(-3)+0.00249478151324 * \mathrm{BM}(-4)-0.64705593 * \mathrm{BK}(-1)+$

$0.163848515362 * \mathrm{BK}(-2)-0.289795406676 * \mathrm{BK}(-3)+0.259709721259 * \mathrm{BK}(-4)$

\subsection{Uji Kausalitas Granger}

Uji kausalitas Granger dilakukan untuk melihat hubungan timbal balik antara variabel yang terlibat. Terdapat dua hubungan yang mungkin terjadi yaitu hubungan satu arah dan hubungan dua arah.

Tabel 4. Uji Kausalitas Granger

\begin{tabular}{ccc}
\hline Hipotesis & Prob & Keputusan \\
\hline Variabel BK te rhadap variabel BM & 0,0084 & $\mathrm{H}_{0}$ ditolak \\
Variabel BM terhadap variabel B K & 0,0993 & $\mathrm{H}_{0}$ diterima \\
\hline
\end{tabular}

Pada taraf signifikansi 5\% dapat disimpulkan bahwa variabel BK mempengaruhi variabel $\mathrm{BM}$ sedangkan variabel $\mathrm{BM}$ tidak mempengaruhi variabel $\mathrm{BK}$.

\subsection{Deteksi Stabilitas Model VAR}

\begin{tabular}{|cc|} 
Tabel 5. Hasil Deteksi Stabilitas & Model VAR \\
\hline Root & Modulus \\
\hline $\mathbf{0 . 9 1 0 1 6 5}$ & 0.910165 \\
$\mathbf{0 . 8 5 6 5 7 2}$ & 0.856572 \\
$\mathbf{- 0 . 7 5 3 3 6 5}$ & 0.753365 \\
$\mathbf{0 . 4 0 1 9 4 6}-\mathbf{0 . 6 2 1 7 9 8 i}$ & 0.740401 \\
$\mathbf{0 . 4 0 1 9 4 6}+\mathbf{0 . 6 2 1 7 9 8 i}$ & 0.740401 \\
$\mathbf{- 0 . 7 2 2 5 3 5}$ & 0.722535 \\
$\mathbf{- 0 . 0 1 6 0 7 4}-\mathbf{0 . 6 8 9 5 1 3 i}$ & 0.689700 \\
$\mathbf{- 0 . 0 1 6 0 7 4}+\mathbf{0 . 6 8 9 5 1 3 i}$ & 0.689700 \\
\hline
\end{tabular}

Dari Tabel 5 terlihat bahwa tidak ada nilai akar karakteristik dan modulus yang lebih dari 1. Hal ini menunjukkan model VAR (4) yang diperoleh dalam kondisi stabil.

\subsection{Uji Asumsi Residual}

\subsubsection{Uji Independensi Model Lag 4}

Uji independensi dilakukan untuk melihat adanya korelasi residual antar lag pada model. Hasil pengujian independensi residual menggunakan uji Portmantaeu, sebagai berikut:

Tabel 6. Hasil Pengujian Independensi Residual

\begin{tabular}{ccccc}
\hline Lag & Q-Stat & $\boldsymbol{\chi}_{\left(\boldsymbol{K}^{2} \boldsymbol{p} ; \boldsymbol{\alpha}\right)}^{\mathbf{2}}$ & Prob & Keputusan \\
\hline $\mathbf{1}$ & 0,265954 & $\mathrm{NA}^{*}$ & $\mathrm{NA}^{*}$ & - \\
$\mathbf{2}$ & 0,665401 & $\mathrm{NA}^{*}$ & $\mathrm{NA}^{*}$ & - \\
$\mathbf{3}$ & 0,950485 & $\mathrm{NA}^{*}$ & $\mathrm{NA}^{*}$ & - \\
$\mathbf{4}$ & 2,261985 & $\mathrm{NA}^{*}$ & $\mathrm{NA}^{*}$ & - \\
$\mathbf{5}$ & 2,485296 & 9,49 & 0,6473 & $\mathrm{H}_{0}$ diterima \\
$\mathbf{6}$ & 3,541114 & 15,51 & 0,8960 & $\mathrm{H}_{0}$ diterima \\
$\mathbf{7}$ & 4,951178 & 21,03 & 0,9596 & $\mathrm{H}_{0}$ diterima \\
$\mathbf{8}$ & 7,985763 & 26,30 & 0,9493 & $\mathrm{H}_{0}$ diterima \\
$\mathbf{9}$ & 8,793850 & 31,41 & 0,9852 & $\mathrm{H}_{0}$ diterima \\
$\mathbf{1 0}$ & 11,75513 & 36,42 & 0,9825 & $\mathrm{H}_{0}$ diterima \\
$\mathbf{1 1}$ & 15,62687 & 41,34 & 0,9710 & $\mathrm{H}_{0}$ diterima \\
$\mathbf{1 2}$ & 28,77906 & 46,19 & 0,6304 & $\mathrm{H}_{0}$ diterima \\
\hline
\end{tabular}


ISSN: 2339-2541

JURNAL GAUSSIAN, Volume 9, Nomor 2, Tahun 2020, Halaman 204-214

Online di: https://ejournal3.undip.ac.id/index.php/gaussian/

\begin{tabular}{ccccc}
\hline Lag & Q-Stat & $\boldsymbol{\chi}_{\left(\boldsymbol{K}^{\mathbf{2}} \boldsymbol{p} ; \boldsymbol{\alpha}\right)}^{\mathbf{2}}$ & Prob & Keputusan \\
\hline $\mathbf{1 3}$ & 30,21335 & 50,99 & 0,7398 & $\mathrm{H}_{0}$ diterima \\
$\mathbf{1 4}$ & 37,97519 & 55,76 & 0,5617 & $\mathrm{H}_{0}$ diterima \\
$\mathbf{1 5}$ & 39,56361 & $\mathbf{6 0 , 1 2}$ & 0,6620 & $\mathrm{H}_{0}$ diterima
\end{tabular}

Pada taraf signifikansi 5\% dapat disimpulkan bahwa tidak terdapat korelasi residual antar lag pada model yang terbentuk.

\subsubsection{Uji Multinormal Residual}

Uji asumsi residual yang harus terpenuhi selain uji independensi adalah uji multinormal. Uji multinormal secara formal sebagai berikut

Tabel 7. Hasil Pengujian Normalitas Multivariat

\begin{tabular}{ccc}
\hline Model & P-value & Keputusan \\
\hline VAR (4) & 0,000 & $\mathrm{H}_{0}$ ditolak
\end{tabular}

Pada taraf signifikansi 5\% dapat disimpulkan bahwa residual dari model VAR (4) tidak berdistribusi normal multivariat.

Berdasarkan Rosadi (2011), dijelaskan bahwa asumsi normalitas tidak sepenting asumsi white noise sehingga multinormal data dapat diabaikan.

\subsection{Analisis Impulse Respon Function (IRF)}

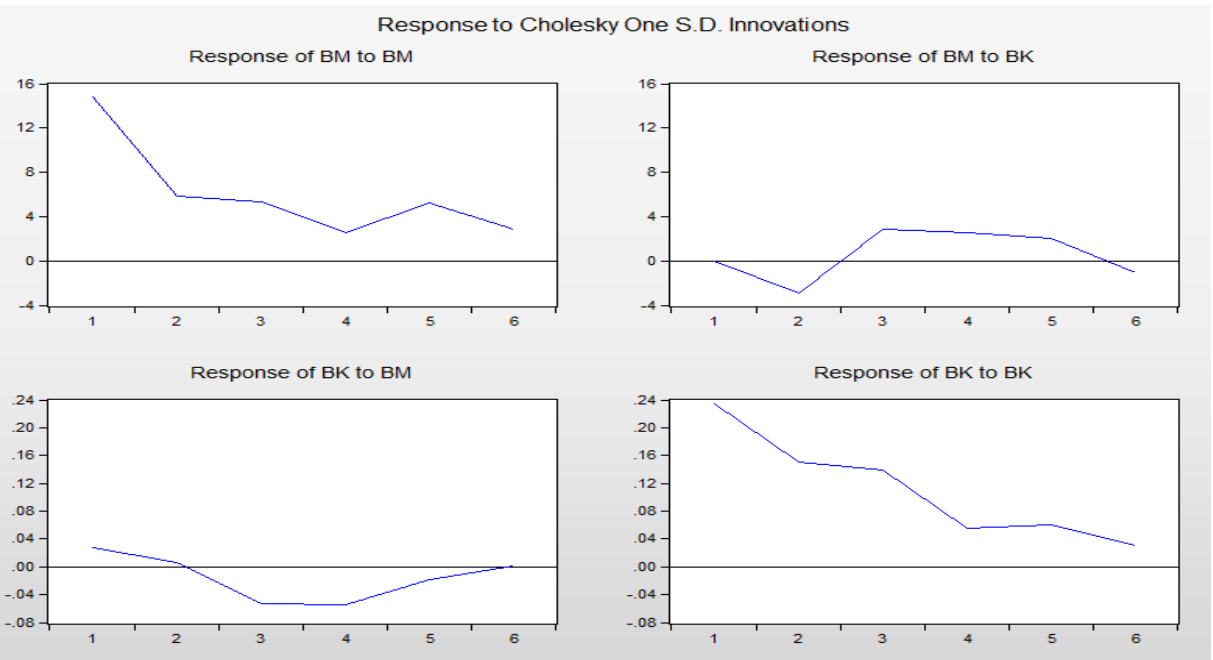

Gambar 4. Hasil Analisis Impulse Respon Function (IRF)

sumbu horizontal menyatakan periode dalam bulan dan sumbu vertikal menyatakan respon terhadap guncangan (shock).

Penjelasan dari grafik-grafik yang terdapat pada Gambar 4 adalah sebagai berikut:

1. Respon dari Bea Keluar (BK) terhadap guncangan Bea Masuk (BM) akan menurun dari awal periode sampai periode ke-4. Guncangan pada Bea Masuk (BM) direspon oleh Bea Keluar (BK) mulai dari periode pertama. Kemudian secara ekstrim respon oleh Bea Keluar (BK) meningkat pada periode ke-5. Respon terus meningkat sampai periode ke-6.

2. Respon dari Bea Masuk (BM) terhadap guncangan Bea Keluar (BK) adalah Bea Masuk (BM) akan menurun dari awal periode sampai periode ke-2. Guncangan pada Bea Keluar (BK) direspon oleh Bea Masuk (BM) mulai dari periode pertama. Respon terus meningkat sampai akhirnya mencapai respon tertinggi terjadi pada periode ke-5. Kemudian mengalami penurunan sampai periode ke-6. 


\subsection{Forecast Error Decomposition Variance (FEDV)}

Tabel 8. Variance Decomposition of Bea Keluar

\begin{tabular}{ccc}
\hline Periode & Bea Keluar & Bea Masuk \\
\hline $\mathbf{1}$ & 98.62362 & 1.376381 \\
$\mathbf{2}$ & 98.98848 & 1.011520 \\
$\mathbf{3}$ & 96.46469 & 3.535312 \\
$\mathbf{4}$ & 93.93369 & 6.066308 \\
$\mathbf{5}$ & 93.86160 & 6.138396 \\
$\mathbf{6}$ & 93.91252 & 6.087478 \\
\hline
\end{tabular}

Berdasarkan Tabel 8, maka dapat diketahui bahwa hasil variance decomposition pada variabel bea keluar untuk forecasterror variance bea keluar menunjukkan bahwa untuk prediksi enam periode ke depan (periode ke-1 sampai periode ke-6) proporsi bea keluar semakin menurun setiap periodenya. Sementara pada variabel bea masuk untuk forecast error variance bea keluar menunjukkan bahwa prediksi enam periode ke depan (periode ke1 sampai periode ke-6) proporsi bea masuk secara berturut meningkat pada setiap periodenya. Hal tersebut menunjukkan bahwa variabel bea keluar diberi guncangan oleh bea masuk pada setiap periodenya mengakibatkan hasil variance decomposition pada variabel bea keluar mengalami penurunan setiap periodenya, sebaliknya bea masuk mengalami peningkatan hasil variance decomposition pada setiap periodenya.

\subsection{Ketepatan Metode Prediksi}

Tabel 9. Nilai Mean Absolute Precentage Error (MAPE)

\begin{tabular}{cc}
\hline Model & Nilai MAPE \\
\hline Bea Masuk (BM) & $18,42 \%$ \\
Bea Keluar (B K) & $12,94 \%$
\end{tabular}

Berdasarkan Tabel 9 Dari nilai tersebut dapat disimpulkan bahwa akurasi untuk model bea masuk dan bea keluar adalah kategori baik karena nilai MAPE berada diantara 10 $\%$ sampai $20 \%$, Nilai MAPE menunjukkan kemampuan model juga baik dalam memprediksikan data

\section{KESIMPULAN}

1. Model VAR(4) yang terbentuk untuk variabel bea masuk (BM), bea keluar (BK) adalah sebagai berikut:

$\mathrm{BM}=13.4677610021+0.415525516978 * \mathrm{BM}(-1)+0.155592518908 * \mathrm{BM}(-2)-$ $0.0915261272713 * \mathrm{BM}(-3)+0.327956634411 * \mathrm{BM}(-4)-12.5431999451 * \mathrm{BK}(-1)+$ $25.610984559 * \mathrm{BK}(-2)-1.58832310159 * \mathrm{BK}(-3) 10.2171979963 * \mathrm{BK}(-4)$

$\mathrm{BK}=0.246086473297-0.000838052009734 * \mathrm{BM}(-1)-0.0037508128 * \mathrm{BM}(-2)+$ $0.000912046162506 * \mathrm{BM}(-3)+0.00249478151324 * \mathrm{BM}(-4)-0.64706 * \mathrm{BK}(-1)+$ $0.163848515362 * \mathrm{BK}(-2)-0.289795406676 * \mathrm{BK}(-3)+0.259709721 * \mathrm{BK}(-4)$.

2. Stabilitas dari model VAR(4) yang telah terbentuk menunjukkan seluruh nilai modulus yang diperoleh bernilai kurang dari 1 yang menyatakan bahwa model VAR tersebut dalam kondisi stabil.

3. Diperoleh nilai prediksi dari model VAR(4) yang terbentuk untuk variabel bea masuk mengalami fluktuasi selama 12 periode dan variabel bea keluar mengalami kenaikan secara berkala mulai dari periode 1 hingga periode 12 pada tahun . 


\section{DAFTAR PUSTAKA}

Ariefianto, M.D. 2012. Ekonometrika. Jakarta: Erlangga.

Granger dan Clive, W. 1969, "Investigating Causal Relationships by Econometric Models and Cross-Spectral Methods", Econometrics, Vol. 37, pp. 424-438.

Lütkepohl, H. 2005. New Introduction To Multiple Time Series Analysis. Berlin: Springer. Juanda, B. dan Junaidi. 2012. Ekonometrika Deret Waktu. Bogor: IPB Press.

Nisa', H.D.K. 2010. Peramalan Debit Air Sungai Brantas dengan GSTAR dan ARIMA. Undergraduate Thesis: Surabaya. Institut Teknologi Sepuluh November.

Ozcelebi, O. 2011. Determinant of Construction Sector Activity in Turkey: A Vector Autoregression Approach, International Jurnal of Economics and Finance, Vol. 3, Hal. 130-139.

Sims, C.A. 1972, "Money, Income and Causality", American Economic Review, Vol. 62, pp. 540-552.

Wei, W.W.S. 2006, Time Series Analysis Univariate and Multivariate Methods. $2^{\text {nd }}$ Edition, Pearson Education, USA.

Wahyuli, A. 2007. Analisis VAR (Vector Autoregressive) Untuk Mekanisme Pemodelan Produksi, Konsumsi, Ekspor, Impor, dan Harga Minyak Bumi. Skripsi. Fakultas Matematika dan Ilmu Pengetahuan Alam, Institut Pertanian Bogor, Bogor.

Widarjono, A. 2005, Ekonometrika Teori dan Aplikasi untuk Ekonomi dan Bisnis, Buku Pertama, Edisi Pertama, Ekonisia, Universitas Islam Indonesia, Yogyakarta. 